\title{
非イオン性界面活性剤と各種化合物との相互作用
}

\author{
刚 米 孝 夫*
}

\section{INTERACTION OF NONIONIC SURFACE ACTIVE AGENTS WITH VARIOUS COMPOUND}

\author{
BY
}

\section{DR. TAKAO KARIYONE*}

Nonionic surfactants are usefull materials in cosmetic industries, which especially are used as emulsifier and solubilizer. Generally, various interaction are observed between surfactants and many compounds.

This paper deals especially with nonionic surfactants.

1. The mechanism of hydration and dehydration, and effects of added inorganic and organic compounds on clouding point are discussed.

2. It seems that the "salting in" effects by produced some polxyvalent cations to contrast with the "salting out" effects of monovalent cations depends on interactions of nonionics with polxyvalent cations.

3. In interactions of nonionics with phenols, which are practically important in connection with effects as preservatives, prevent action of nonionics are reviwed.

These facts are also applied to phenol titratiom method which estimates hydrophilic degrees of nonionics.

4. Interactions of nonionics with organic acids are found between high molecular glycols (polyoxy) and polyacrylic acids and between nonionics and grugs.

5. Mixtures of urea and liquid nonionics will solidfy to a hard cake on standing. This phenomenon is obserbed only on compounds having a normal long hydrocarbon chain and polyglycols (carbowax etc.).

6. The best known complexes of nonionics with halogens are the "Iodophors" which result from the admixure of iodine crystals and nonionics.

These have a powerful germicidal properties. Recently, a new method for the determination of critical micelle concenttation of nonionics is developed, and shown to be applicablein a number of different solvents.

The method depend on the formation of colored iodine micelle complex.

I think it is desirable to consider these interactions on selection of nonionics and these Interactions are applicable to estimate amphiphacy of surface active agents.

\section{1. まえがき}

化粧品工業において乳化剂, 可溶化剂として最も良く 使用されるのはポリオキシェチレン系非イオン活性剤で ある。このものはアルコール, カルボン酸, フェノール アミンなど活性水素をるつ疎水基に酸化ェチレンを付加 縮合することによって得られる一群の界面活性物質であ る。また湿潤剤としてポリェチレングリコール（分子量

※ 花王石䇾株式会社研究所, 次長, 工博

* centRal RESEARCH laboratory of KAO SOAP CO, LTD. ASSISTANT DIRECTOR
200〜6,000）や増粘剤，凝集剤としてさらに高分子量の ポリエチレングリコール（分子量10万〜数百万）も化栍 品原料として用いられることが多い。

一般にポリオキシェチレン誘導体は化学的に比較的安 定な物質であり生物学的, 生理学的にも不活性で微生物 による分解性も小さく毒性もきわめて低いことが知られ ている。しかしながらポリエチレンオキサイド構造を持 つこれらの化合物が各種物質との相互作用と考えられる さまざまの実験結果や，機構の解明が試みられており， 最近これらに関する綜説1 もみられる。 
本鮦ではポリオキシェチレン誘導体の水和性, 多価イ オン, フェノール，有機酸ハロゲンなどとの相互作用な らびに尿素付加物について紹介乙界面活性倣を御利用頂 く上の御参考に供したい。

\section{2. 水 和 性}

ポリホンシェチレン系非イオン活性剤を水に浴かすを 水分子法水素結合によってェーテル状酸素原子に付加を ること在 chwala と Mastina ${ }^{2}$ が明らかにした。

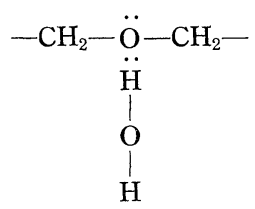

この結合は比較的弱く加熱によって脱水和が扣こり, 混 濁, 分離を和こす。この温度は曇点とよばれポりオキシ エチレン鎖が長いほど高い。中川阳光散乱によるミセ 儿量測定ふら量点現象の機構を"温度上昇につれてポリ オキシェテレン基と水分子との水素結合が弱をり脱水和 が起らてミセルが大きくなり，しかも高温になるほど怔 速度的に顕著になり西る温度に達すると肉眼にも滥りが み充会くらいにミセルが生長する。これが量点である” と説明している。

Wurzschmitt ${ }^{4)}$ はポリオキシェチレン誘導体分析の系 統的研究うら,これらは水溶液中で陽イオン性のポリオ キソニシウム化合物として存在することを示唆した。

$$
\left[-\mathrm{CH}_{2}-\stackrel{\mathrm{O}}{\mathrm{O}}-\mathrm{CH}_{2}-\right]^{+}[\mathrm{OH}]^{-}
$$

さらにェーテル酸素原子すべてがオキソニウム塩を形 成しているのではなく，その一部分のみでこの割合をオ キソニウム度として示し珠タングステン酸などのへテロ ポリ酸にニる沈澱反応を解析した。ポリオキシェチレン 化合物の沈澱剤としてはこの他にリンモリブデン酸, フ エロンアン酸, ヨウ素, タンニンなどが知れている。

ボリオンシェチレン誘導体の水溶液は塩類, 塩基によ って孔脱水和が起るが酸類では脱水和されにくい。これ は酸類がニーテル状酸素とオキソニウム化合物を作り易 いため上考えられる。

Evans $^{2}$ (2ホホリオキシェチレンオクチル.フェノールェ ーチル $(8.5$ モル) 水溶液に電解質を添加した場合の量 点家測定し（図-1）量点の低下能はアニオンでは

$$
\begin{aligned}
\text { Citrate } & -->\mathrm{SO}_{4}^{--}>\mathrm{OH}^{-}>\mathrm{HSO}_{4}^{-}>\text {Acetate } \\
& >\mathrm{BrO}_{3}^{-}>\mathrm{Cl}^{-}>\mathrm{NO}_{3}^{-}>\mathrm{I}^{-} \\
\text {力チ六ンで法 } &
\end{aligned}
$$

$$
\mathrm{Na}^{+}>\mathrm{K}^{+}>\mathrm{Cs}^{+}>\mathrm{Mg}^{++}>\mathrm{Ca}^{++}>\mathrm{Li}^{+}
$$

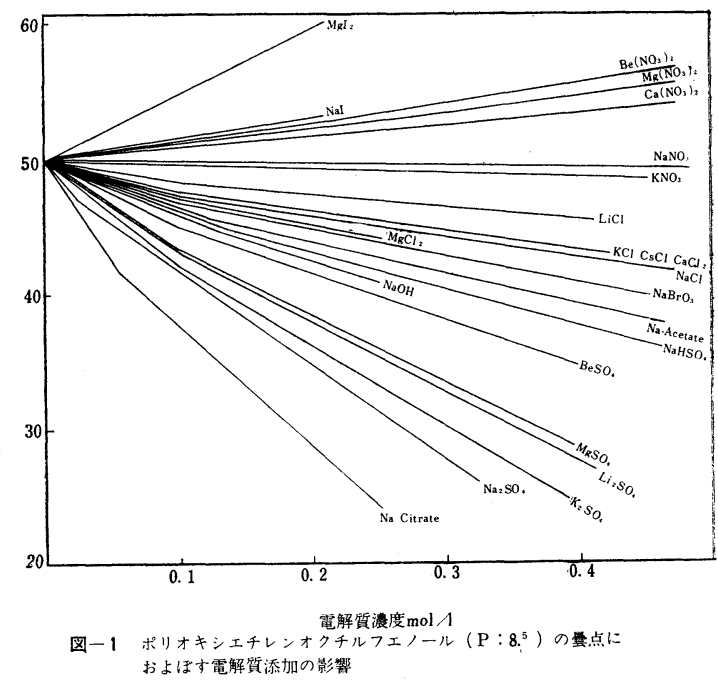

の順に大きいことを報告している。この順位はイオンの 離液順位とは異なっている。

有機化合物の添加の量点に及注す影響についてはMaclay $^{6)}$ のポリオキシェチレンオクチルフェノールェ テル（9.5モル）についての報告があり（図-2）これに よると一般に非極性物質や㓌イオン性活性剂は曇点之上 昇させ芳香族物質や極性脂肪族化合物は低下させる。

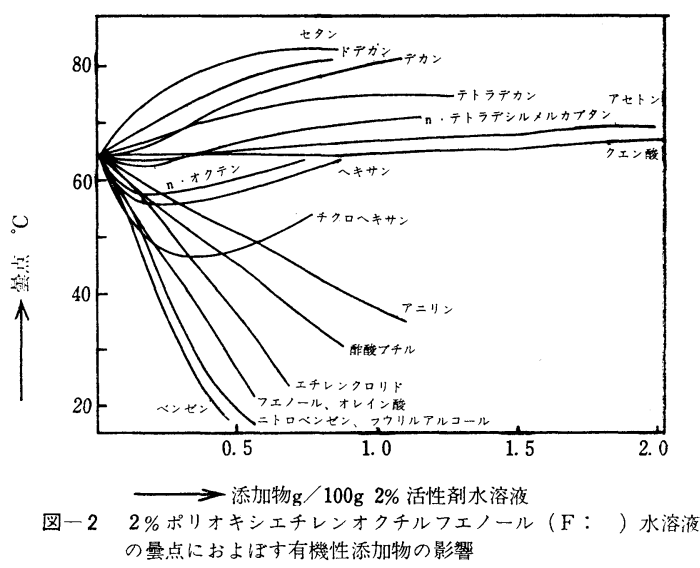

\section{3. 多価イオンとの相互作用}

ポリオキシェチレン誘導体水溶液に無機塩を添加した 場合, 多価カチオンは最点の低下能が小さいことを前項 で述べたがある種のカチオンでは活性剤の水和性を増加 させる現象が観察されている。

Doscher ${ }^{7}$ ) $30 \%$ cacl $_{2}$ 水溶液を $5 \%$ Renex (Atlas社， ポリオキシェチレントール油エステル）水溶液に加光た 場合に生じた沈澱を分別しイソプロパノールから繰返し 再結晶することにより無定形, 淡黄色の粉末を得た。 
の化学的分析持よびX線解析からこの構造は $3 \mathrm{cacl}_{2}$, $15 \mathrm{H}_{2} \mathrm{O} ・ 1$ Renex であることを確証し, 水和したカルシ ウムイオンが陰イオン性のポリェーテル酸素と結合しコ ンプレッスを生成するものと孝えた。

Colwell ${ }^{11}$ らはポリオキシェチレンノニルフェノール エーテル (10.5 モル) の曇点に及ぼす無機塩添加の影響 をしらぺた結果 $\mathrm{Cacl}_{2}$ では添加量の少ない場合図-1と同 椂に低下の傾向があるが，さらに添加量を増加すると量 点は次第に上昇し活性自身の示す最点より高くなること を認め（図-3）これは明らかに $\mathrm{Ca}^{++}$との間に会合錯塩 をつくっているものと推論している。

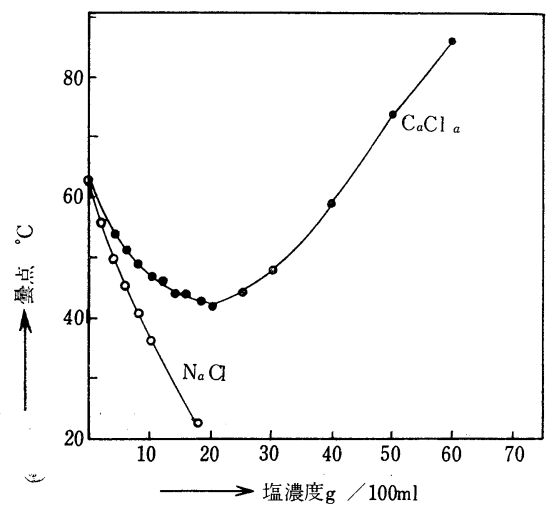

図一-30.5\%ポリオキシエチレンノニルフエノールエーテル $(\overline{\mathrm{P}}: 105)$ の篔点におよぼす塩添加の影響

同様に高分子量のエチレンオキサイドポリマーである Polyox WSR_301 (Union Carbide \& carbon) につい て無機塩添加の影響を粘度, 量点についてしらべた結果 は図-4に示すように $\mathrm{Cacl}_{2}$ の添加は粘度を上昇させる結 果となりこれはその高分子に対してょり良溶媒であるこ とを示すもので溶媒親和性が大きく高分子が拡張した形 状であることが推論されよう。

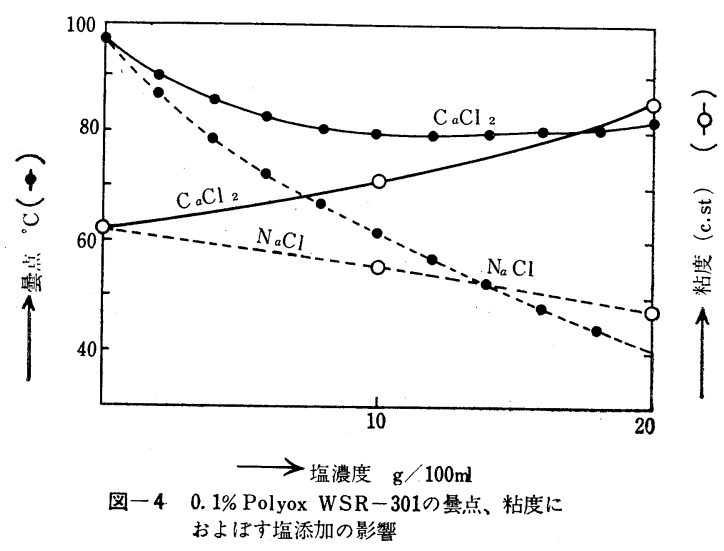

Van Strien の特許 ${ }^{8)}$ によれば多価金属イオンと一価 アニオンの塩または低分子量アルコールとアルコラート を作る塩はポリエチレングリコール誘導体とコンプレッ クスを作ることを報告して打り $\mathrm{Cacl}_{2}, \mathrm{Mgcl}_{2}, \mathrm{Cucl}_{2}$, $\mathrm{Zncl}_{2}$, との生成物は液状の非イオン活性剤を固型化し たり, ガソリン, 潤滑油, 動植物油などの有機液体のゲ ル化剂して有用であり，また石油採堀に和ける堀さく泥 に添加したり水を含まないハンドクリーナー，などへの 利用も考光られる。

ベントナイトなどのコロイド分散系の安定系にもこの コンプレックス形成が利用され, 例えば高濃度の塩類浴 液中で凝集が起る原油一ベントナイト系に $\mathrm{Cacl}_{2}$ 一非イ オン活性剤を添加することによりこれを防止することが できる。これは $\mathrm{Ca}$ 一ベントナイト表面へのポリグリコー ル鎖の優先的な吸着によって活性剤の親油性部分が外測 を向き親水性コロイドを油相中に安定化するものと考え られカルシウムが粘度粒子とポリグリコールの閒を架橋 する役割を果すと考えられる。

この他, Doscher らては種々の非イオン活性融を加え て安定化した金ゾルは $\mathrm{Ca}^{++} よ り る \mathrm{Na}^{+}$によって凝集し やすいが界面活泩剤を含まない同じ金ゾルでは逆に $\mathrm{Na}^{+}$

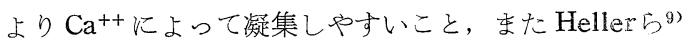
はポリエチレングリコール系化合物で予めゾルを処理し た場合、イオンによる凝集に対して安定化されることな どの興味ある報告がみられる。

\section{4. フェノール性化合物との相互作用}

ポリエチレンオキサイド構造をむつ化合物とフェノー ルおよびその誘導体をの相互作用については多くの郝告 がみられる。とくに化粧品, 医薬の分野に和いて防瓷 剤, 防カビ鼡, 殺菌剤などフェノール性基をもつものと の間には，それの効力減少の形で認められており，機棈 的にはポリェーテル酸素とフェノール性ヒドロキシル基 間の水素結合によるものとして知られている。

化粧品に用いられる防窝剤と非イオン活性剤の組合せ については de Navarre ${ }^{10)}$ Wedderburn $^{11)}$ の一連の実 験報告があり, 活性剤, 微生物, 防腐剤ないし殺菌剤を 広汎に変えてその相互作用をしらべている。

Kasten bauder ${ }^{12)}$ はp-オキシ安息香酸エステルと各 種物質との相互作用の程度を知るためにナイロン膜の透 析によって高分子物質と防扁剂の結合量をしらべこれの 多いもの程不活性化の程度が大きいことを示している。

青木ら ${ }^{13)}$ は p-オキシ安息香酸エステル類を Tween 20 を用いて可溶化した場合について抗カビ効果をしらべた 結果, ブチルェステルよりメチルェステルの方が抗力ビ 
表-1 各種高分子物質に対する $\mathrm{p}-$ オキシ安息 香酸の結合度

\begin{tabular}{|c|c|c|c|c|}
\hline \multirow{2}{*}{ 高分子物質 $2 \%$} & \multicolumn{2}{|c|}{$\begin{array}{l}\text { メチルパ } \\
\text { ラベ ン }\end{array}$} & \multicolumn{2}{|c|}{$\begin{array}{l}\text { プロ ピル } \\
\text { パラ ペン }\end{array}$} \\
\hline & $\begin{array}{c}\text { 遊離量 } \\
\%\end{array}$ & $\begin{array}{l}\text { 結合量 } \\
\%\end{array}$ & $\begin{array}{c}\text { 遊離量 } \\
\% \%\end{array}$ & $\begin{array}{l}\text { 給合量 } \\
\%\end{array}$ \\
\hline ゼラチン & 92 & 8 & 89 & 11 \\
\hline メチルセルローズ & 91 & 9 & 87 & 13 \\
\hline カーボワックス 4000 & 84 & 16 & 81 & 19 \\
\hline ポリビニル・ピロリドン & 78 & 22 & 64 & 36 \\
\hline "Myrij 52" & 55 & 45 & 16 & 84 \\
\hline "Tween $20 "$ & 43 & 57 & 14 & 86 \\
\hline "Tween $80 "$ & 43 & 57 & 10 & 90 \\
\hline
\end{tabular}

カが大でこれはブチルエステルはミセル中に可溶化され るのに刘してィチルェステルはミセルに入り難いためと 推論した。また他のフェノール性殺菌剤や異種構造のオ キシェチレン系活性剤についても実験し，活性剤を含む 水溶液を抗力ビ性にするためには系全体に加えた抗カビ 剤の総量よりも水相中に存在する濃度が重要であり, セル中に入った抗カビ剤はミセル外にあるものと平衝し て和り水相中のものが消費されたときこれを補給するタ ンクのような機能をもっと考兄られるが14)いずれにして も水相中の濃度が有效濃度以上を保ち得るようなバラン

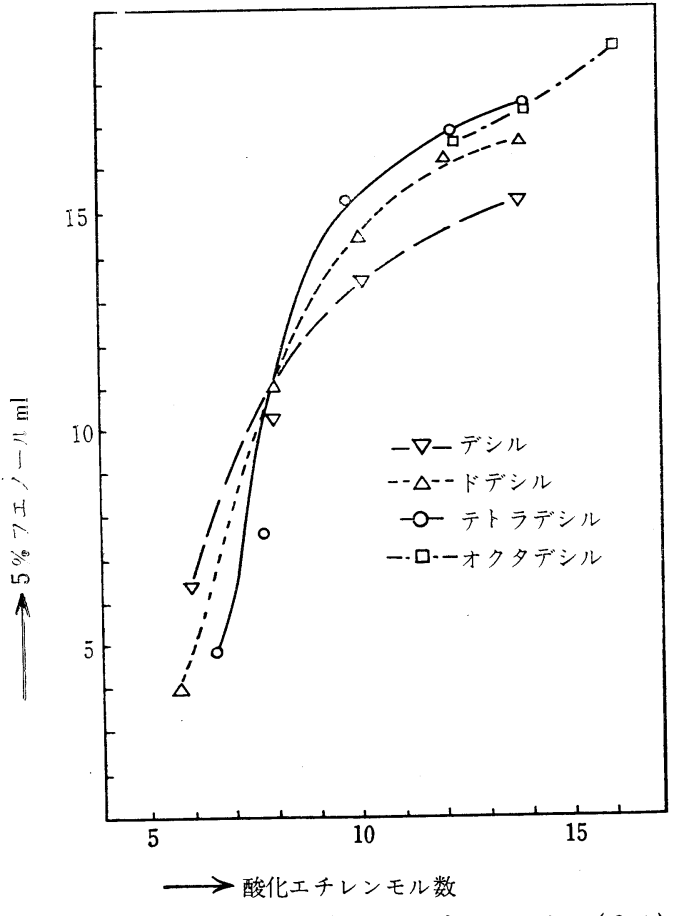

図一5 ポリオキシエチレンアルキルエーテル（2\%）の モル数変化とフエノール消費量
スをその系に与えることが必要である。

このような非イオン活性剤による不活性化を防止する 手段としてはカチオン活性剤との併用や一価玉たは多価

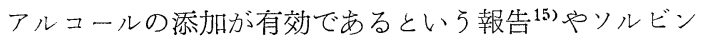
酸の効果も発表(6)されている。

一方これらの現象をオキシェチレン系非イオン活性剤 の親水度の評価浪利用する試みが括こなわれており，そ の 1 部を例示する。

Karabinos $^{17)}$ は $1 \mathrm{~g}$ の活性剤を $50 \mathrm{ml}$ の蒸溜水に 溶か

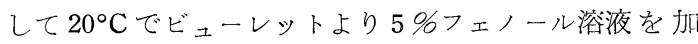
えオパール状の濁りが認められる点を終点とした。 $\mathrm{C}_{10 \sim 18}$ のアルキル鎖をもつポリオキシェチレンェーテルについ ての測定結果は図-5に示すようにオキシェチレン鎖長の 増加と共にフェノール消費量は増し構造既知のものにつ いてはこれからオキシェチレンモル数を推定できること を報告している。

Davis ${ }^{18)}$ らは活性剤を水又は塩水に浴かし $2 \%$ フェ 一ル溶液で滴定し活性剂浱度と消費フェノール浴液量と の関係が図-6に示すように直線的であることから非イオ ン活性剤の濃度管理に使用できると述べている。

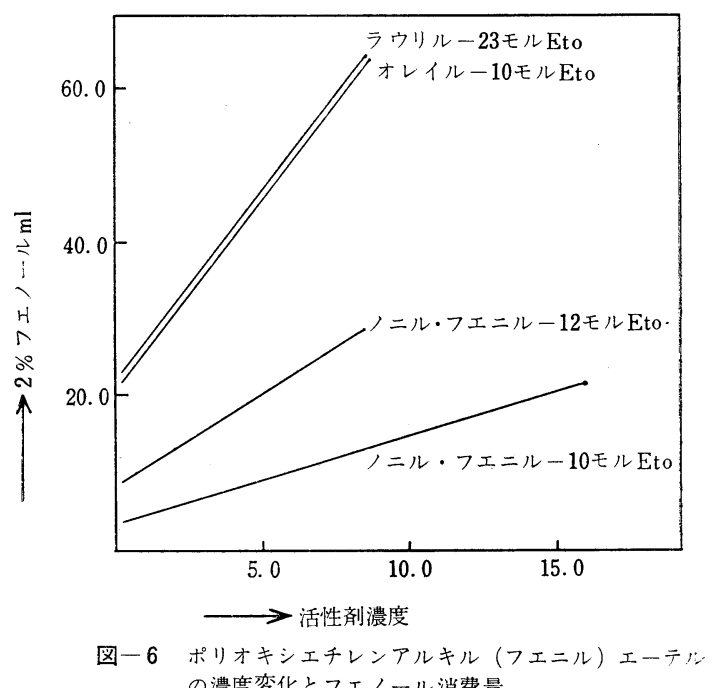
の濃度変化とフェノール消費量

田中 ${ }^{199}$ は水に不溶性ないし分散性の活性剂にも適用性 を拡張し，溶媒としてェタノールまたはプロピオン酸を 用いる方法を報告している。実験の 1 例を図-7亿示す。

この他ポリオキシェチンン基をるつ非イオン活性剤と フェノール誘導体の間の難溶性物質の生成に関しては Meiden $^{20)}$ らや Livinngston ${ }^{21)}$ もこれを認めており Higuchi らはカーボワックスとフェノール類の間にコン 


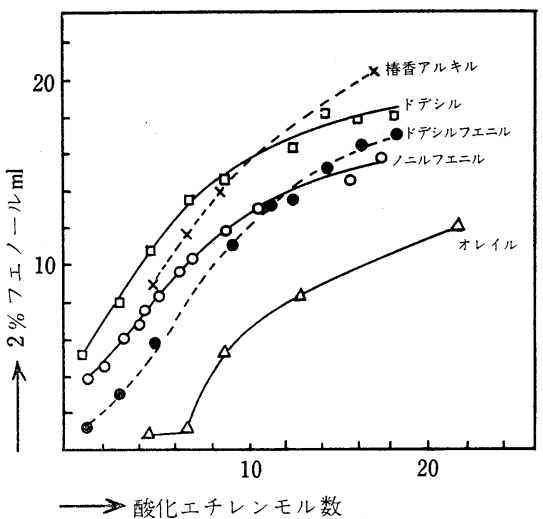

図一7 ポリオキシエチレンアルキル (フエニル) エーテルの モル数とフエノール消費量の関倸（10\%エタノール溶液）

プレックスの生成を推定している。また Mulley ら ${ }^{23)}$ はェーテル型非イオン活性剤とフェノールの間のコンプ レックス形成について論じている。

\section{5. 有機酸との相互作用}

ホリエチレンオキシドを含む製品と有機酸類と相互作 用の最も良い例は高分子ポリグリコール (Polyox) 水 溶液とポリアクリル酸水溶液の混合の場合にみられる。

Petersen $ら^{24)}$ はこの場合について広範囲の混合組成 で水に不溶性のコンプレックスが生成することを認めこ こに得られたゴム状の樹脂の性質, 構造を詳細に報告し ている。この相互作用はやはりオキシェチレン鎖のェ一 テルとカルボキシル基との間の水素結合によるものと考 觉られる

Chakravarty $ら^{25)}$ は Myrij 52 (ポリー(40)ーオキシ エチレンステアレート，Atlas）と多くの有機酸との間 のコンプレックス形成能について研究をおこない, $\mathrm{p}$ 一七 ドロキシ安息香酸, $\mathrm{p}$-アミノ安息香酸, $\mathrm{m}$ 一ヒドロキシ安 息香酸、安息香酸, アセチルサリチル酸では活性剤の添 加によって水中での浴解度が増加することを認めた。こ れはフェノールやレゾルシノールが活性剤によって不溶 化するのと全く逆の現象である。

Marcus $^{26)}$ によればカーボワックスをべースにした座 薬にアスピリンを加えるとワックスベースが非常に軟ら かくなり，また吸収速度が著しく減少することを認めこ 就ら相互関係について考察している。

\section{6. 尿素付加物}

ポリオキシェチレン基をもつ非イオン活性剤の多くは 油状ペースト状ないしはろう状で粉末洗剤や粉末型態 の製品に利用するには不便なことが多い。

Bengen, Schlenk ら ${ }^{27)}$ にって見出され，発展した
尿素による包接化合物形成の考え方は Zimmerschied $ら^{281}$ によって石油中の直鎖パラフィンを尿素付婔物で分 離するという方面に実用化されている。

一方 Barker $5^{2930)}$ はポリオキシェチレン丁ルキル エーテル，アシルェステル，アミン,アマイド誘導休を尿 素と混合することにより固型化に成功し，得これた固体 がその含有する活性剤と作用の点で変りないことを報告 している。付加物の構造は Schiessler ら ${ }^{31}$ によりて解 明され，これによれば尿素は普通正方晶系で㐫っ力゙䞆 の脂肪族化合物と混合すれば 6 方晶系の結晶:こなり尿素 分子の形成するラセン状の 6 角筒の中に包又こ杰れてい る。尿素の形成する筒の内経は約 $5 \AA$ で有りこれより小 さい分子は付加物を作るが大きな分子例えば分佒化合物 や環状化合物はこれをつくらない。したがって非イホン 活性剤の場合ポリオキシェチレン脂肪アルコール．脂肪 酸エステルやポリエチレングリコール（カーッッック ス）はその分子の形から考えて付加すること泫当然子想 されるがソルビタン系やアルキルフェノール誘樽作では ソルビタン環，ベンゼン核，分汥鎖が大きく尿素の彩成 する简に入らないから包接化合物を作らないと考えられ る。

美間 ${ }^{32)}$ はこれらを実験的に確認しポリオキシニチレン 脂肪酸エステルとポリオキシェチレンソルビタン脂㭊酸 エステルの分別に応用でき系統的分析への利用梠示唆し ている。付加物の単位結晶の長さはラセン構造に沿って 約 $11 \AA$ で有りこれはオキシェチレン鎖がジグザ型を とるとすれば 3 モルの長さに相当する。した亦りてオキ シェチレン 1 ケ当り 2 モルの尿素が最適比率と索る。ボ リエチレングリコールについて計算すると尿素73\%， ボ リグリコール27\%となり実験結果もこれに近似にた配命 で得られている。

n.

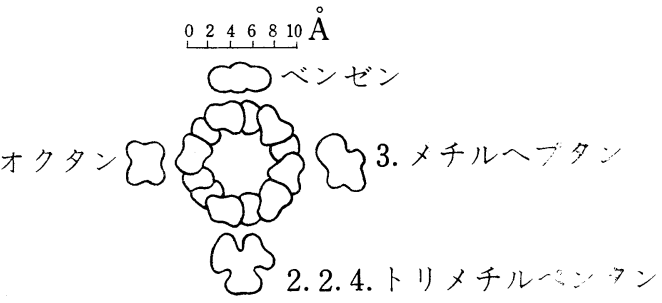

図一8 尿素付加物のトンネル断湔積 と分子の大きさの比較

\section{7. ハロゲンとの相互作用}

ポリオキシェチンン誘導体と八ロゲンとの相互作用と して最も良く知られているものは，ヨードホールである 
5。

ヨードホールはポリオキシェチレン系非イオン活性剤 水溶液にヨウ素の結晶を添加して可浴化することにより 得られ，ノニルフェノール系や Pluronics 型の活性剤 ぶ良く用いられる。ヨウ素と非イオン活性剤とのコンプ レックスは消毒効果に乏しく存在するヨウ素の15２２％ は化学的に結合され消毒㓣としては無効である。1〜3 のョウ素を含むとヨードホール1/3000亿稀釈しても細菌 に対して有効である。ヨードホールは水に溶けて黄色の 透明液をつくる。可溶化剤としての非イオン活性剤の存 在によって同時に湿潤, 洗浄などの効果も期待される。こ れらの組成や紹介については多くの特許 ${ }^{33)}$ や報告 ${ }^{34) 35) 36 \text { ) }}$ 於亦る。

Ross ら ${ }^{37)}$ は非イオン活性剤の臨界ミセル濃度（C. M.C) の測定法核コン゚レックス生成を利用した。すな わち非イオン活性剂浴液にヨウ素浴液を加えるとヨウ素 の色調が変化することを基礎とし水以外の溶媒にも適用 ごきることを報告している。種々の条件下でのヨウ素の 極大吸収は次のようである。

$\mathrm{I}_{2}$ (蒸気) $512^{m \mu}$

$\mathrm{I}_{2} / \mathrm{CCl}_{4} \quad 510$

$\mathrm{I}_{2} / \mathrm{C}_{6} \mathrm{H}_{6} \quad 300,490$

$\mathrm{I}_{2} / \mathrm{H}_{2} \mathrm{O} \quad 450$

$\mathrm{I}_{2}$-ミセルコンプレックス 360

$\mathrm{I}_{2}-\mathrm{KI}$ コンプレックス/水 288,353

一定量のヨウ素の存在下に打惯界活性剂濃度を 360 $m \mu$ の́吸光度に対してプロットすると屈折点を有する 2 直線を示しその屈折点の濃度が C. M. C に相当すること を述べて拁り表面張力法や屈折率の変化から求めた值と 良く一致することを報告している。

松本ら ${ }^{38}$ 性イオン活性剂水浴液にヨウ素を添加して ゆくと濁りを生ずることからこれを”ヨウ素数”として 表わしそれが界面活性剈のエチレンオキシド付加モル数 之直線関係にあることを報告しており，さらに希薄な状 態で紫外部吸収スペクトルを測定し $\mathrm{I}_{2}-\mathrm{KI}$ 水溶液が示す 吸収極大 $350 \mathrm{~m} \mu$ が界面活性剤を添加して行くとき，初 的は水溶液中に単分子状に分散してスペクトルに影響し ないが，西る濃度に達するとミセルを形成しこのミセル ぶヨウ素とコンプレックスを生成してこれがスペクトル に現われる。したがって吸収極大波長の移動開始濃度は その界面活性剤の CMC であるとしてェチレンオキシド 付加モル数との関係を求めている。

\section{8. むすび}

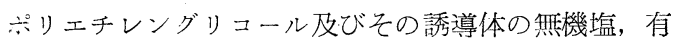

機薬品に対する相互作用について水，重金属イオン，フ エノール, カルボン酸, 尿素, ヨウ素を例にこれ音での 報告を整理してみた。水素結合によっておこるこれらの 相互作用は主剤を不活性化したり溶解度を減じたりする 場合があるがこの現象を利用して活性剤の親水度や両親 媒性を評価することが行わ机ている。またヨウ素との相 互作用の場合のよ5にヨードホールが殺菌郕として利用 されたり一方C MC の測定にヨウ素とのコンプレックス を使用するなど相互作用を積極的に利用すること可可能 である。これらの相互作用を考虑した上で非イオン活性 剤の使用条件を設定する必要があろう。この他イ方性 活性剤や高分子物質との相互作用について子興味㐫る問 題が考光られる。

\section{參考交献}

1) Colwell, Livengood, J. Soc. Cosmetic chemist's 13, 201 (1962)

2) Chwala, Martina, Melliand Textilber. 18, 992 (1937)

3）中川, 通, Kolloid Z. 168, 132 (1960)

4) Wurzschmitt, Z. Anal. Chem. 130, 105 (1950)

5) Durham, "Surface Activity and Detergency" p. 21 (1961) Macmillan \& Co, Ltd.

6) Maclay, J. Calloid Sci, 11, 272 (1956)

7) Doscher, Meyers, Atkins, ibid 6, 223 (1951)

8) Vanstrien, U. S. Patent 2, 826, 265 (1958)

9) Heller, Pugh, J. Polymer Sci. 47, 203 (1960)

10) de Navarre et al, J. Soc. Cosmetic chemist's 7, 427 (1956); 8, 68, 371(1957) 12, 280 (1961)

11) Wedderburn, ibid 9, 210 (1958)

12) Barkley, Am, Perfumer Aromat. Docut, Ed. 1, 101 (1960)

13）青木ら,薬誌 78, 939 (1956); 77,410, 1071(1957)

14) Riegerman, Allacvalla, J, Am. Pharm. Assoc. 42, 376 (1953)

15) de Navarre et al, J. Soc. Cosmetic Chemist's 10, 81 (1959); Am. Perfumer Aromat. Docut. Ed. 1, 110 (1960)

16) Charles, Carter, J. Soc. Cosmetic chemist's 10 , 383 (1959); Am. Perfumer Aromat. 75, (4) 55 (1960)

17) Karabinos, Soap Chem. Specialities 31, (6) 50 (1955)

18) Davis, Wattman, Speel, ibid 31, (12) $73\left(195_{5}\right)$ 
19) 田中, Proc. and Intern. Congress of Surface Activity 4, 132 (1957)

20) Weiden, Norton, J. Colloid Sci. 8, 609 (1953)

21) Livingston, ibid 9, 365 (1954)

22) Higuchi, Lach, J. Am. Pharm. Assoc. Sci. Ed. 43, 465 (1954)

23) Mulley, Matcalf, J. Pharm. Pharmacol. 8, 774 (1956)

24) Smith, Winslow, Petersen, Ind. Eng, Chem 51 1361 (1959)

25) Chakravarty, Lach, Blaug, Drng standards 25, 137 (1957)

26) Marcus, Drug Cosmetic Ind. 79, 456 (1956)

27) Schlenk, Ann. 565, 204 (1949)

28) Zimmerschied et al, Ind. Eng. Chem. 42, 1305 (1950)

29) Barker et al, U. S. Patent 2, 559, 583; 2, 559, 5
84(1951) 2, 665, 256 (1954)

30) Barker, Ranauto, J. Am. 0i1 chemist's Soc, 32 249 (1955)

31) Schiessler Flitter, J. Am. Chem. Soc. 71, 1720 (1950)

32）美間, 薬誌 79, 857 (1959)

33) Brit. Patent 703, 091 (1954)

Sutton, Reynolds. U. S. Patent 2, 759, 869(1956)

Brost, Drupin, Woodward. U. S Patent 2,989, 434 (1961)

34) Cantor, Shelanski, Soap Sanit, chemicals27, (2) 133 (1951)

35) Gershenfeld et al, Soop chem. Specialities 31 , (5) 164 (6) 161 (1955) 32, (9)155(10) 167(1956)

36) Brost, Krupin, ibid 33, (8) 93 (1057)

37) Ross, Olivier, J. Phys. chem. 63, 1671(1959)

38）松本, 見城, 油化学 10, 418, 683 (1961) 